\title{
HISTOPATHOLOGY AND SEROLOGY REACTION TO AN IMMUNE COMPLEX INFECTIOUS BURSAL DISEASE VACCINE (V877 STRAIN) IN SPF AND COMMERCIAL BIRDS
}

\author{
REAÇÃO HISTOPATOLÓGICA E SOROLÓGICA A UMA VACINA DE IMUNOCOMPLEXO \\ CONTRA GUMBORO (CEPA V877) EM AVES SPF E COMERCIAIS
}

\author{
E. C. MUNIZ ${ }^{*}$, M. S. RESENDE ${ }^{1}$, A. F. A. SILVA ${ }^{1}$, R. VERDI ${ }^{1}$, J. DI FABIO ${ }^{2}$, \\ E. L. BORDIN ${ }^{2}$
}

\begin{abstract}
SUMMARY
The purpose of this study was to investigate the effect of a new infectious bursal disease (IBD) immune complex vaccine on immune system response in both specific pathogen-free (SPF) and commercial birds. Evaluation of response to the vaccination in the two experiments was done by histopathological examination and serology. The results of this study have shown that immune complex vaccine with the V877 strain is quite safe in White Leghorn SPF birds in which there has been no participation of maternal antibodies. In commercial birds was also observed that the immune complex vaccine with the V877 strain acted synergistically with different levels of passive antibodies and the vaccine virus began to replicate as passive immunity decreased to provide the animal active immunological response.
\end{abstract}

KEY-WORDS: Immune complex vaccine, Gumboro, serology, histopathology, poultry.

\section{RESUMO}

O objetivo desse estudo foi investigar o efeito de uma nova vacina de imunocomplexo contra a doença de Gumboro sobre o sistema imune de aves SPF e comerciais. A avaliação da resposta à vacinação foi realizada por meio de exame histopatológico e sorologia. Os resultados desse estudo demonstraram que a vacina de imunocomplexo com cepa V877 contra Gumboro é muito segura mesmo em aves SPF da linhagem White Leghorn nas quais não existia a participação de imunidade materna. Em aves comerciais também foi demonstrado que a vacina de imunocomplexo com a cepa V877 atuou sinergicamente com diferentes níveis de anticorpos passivos maternais, iniciando a replicação do vírus vacinal a partir do momento que a imunidade passiva diminui, para promover uma resposta imunológica ativa.

PALAVRAS-CHAVE: Vacina imunocomplexo, Gumboro, sorologia, histopatologia, aves.

\footnotetext{
${ }^{1}$ Zoetis Ind. de Produtos Veterinários Ltda. Avenida Dr. Chucri Zaidan, 1240 - $4^{\circ}$ andar Morumbi Corporate - Ed. Diamond Tower São Paulo - SP, Brazil 04711-130. Email.: eduardo.muniz@ zoetis.com

${ }^{2}$ JF Laboratório de Patologia Animal Ltda. Rua Santo Antônio Claret, 170 - Jardim Chapadão, Campinas - SP, Brazil 13070-145.
} 


\section{INTRODUCTION}

Infectious bursal disease (IBD) has been a constant problem for the commercial chicken industry since its discovery in Delaware, USA, in the late 1950s (MÜLLER et al., 2012). The only effective way to provide protection against this harmful virus is by vaccinating receptive animals at the proper time. In young commercial chicks, high levels of maternal antibody may persist, which in turn can prevent traditional live vaccines from inducing active protection after single or repeated application (BLOCK et al., 2007). Live vaccines contain artificially attenuated live virus grown in eggs or cell cultures. There are different types of attenuated vaccines for IBD and may vary according to the virus titer per dose and the nature or degree of attenuation of the selected infectious bursal disease virus (IBDV) strain. Based on the degree of attenuation, these vaccines can be classified as mild, intermediate, intermediate plus or hot, which are the closest to field viruses (OIE, 2011). Nowadays, immune complex and vector vaccines, as well as conventional vaccines, are currently used in Brazil to control Gumboro disease (MUNIZ et al., 2017).

IBD immune complex vaccines prepared by combining a live attenuated vaccine strain with a specific antibody to IBVD have been developed for use in both in ovo or subcutaneous (s.c.) routes to overcome this common threat. The main goal of this type of vaccine is to face potentially high levels of passive antibody by providing protection for the vaccine antigen. A great advantage to this type of vaccine is that it can be administered on the first day of life without being inactivated by passive antibodies (IVÁN et al., 2005).

Studies on the mechanism of action of this technology have shown that the vaccine virus is detected in the bursa of Fabricius in SPF birds before to 14 days post-vaccination and in broilers with maternally derived IBDV-specific antibodies after 17 to 21 days. Association of the antibody with the vaccine virus is considered strong, as it prevents the inactivating effect of maternal antibodies as well as attenuates the level of lymphocyte depletion in experimentally vaccinated birds (JEURISSEN et al., 1998).

The aim of this study was to investigate the effect of a new IBD immune complex vaccine on the immune response in SPF and commercial birds.

\section{MATERIAL AND METHODS}

\section{Vaccine}

A new immune complex vaccine (V877 strain mixed with antiserum BDA) - Poulvac Magniplex, manufactured by Zoetis - was investigated as part of two experiments that evaluated histological and serological responses in specific pathogen-free (SPF) and commercial birds.

\section{Experiment 1 - SPF birds}

300 SPF eggs were randomly divided into 3 groups. After hatch, only 75 animals per treatment were used.

All birds used in this experiment were White Leghorn breed of SPF origin (Valo BioMedia, Brazil). The sourcing of all eggs and/or animals used in this study was done under the responsibility of the Brazilian Center for Research on Animals (CPABR, acronym in Portuguese), in Amparo, São Paulo.

The treatments were divided as follows: T01 consisted of 75 birds unvaccinated as a negative control. In treatment T02, 100 eggs per group were vaccinated with immune complex vaccine at 18 days of incubation (in ovo vaccination) to have 75 viable birds. In treatment $\mathrm{T} 03,75$ birds per group were subcutaneously vaccinated with immune complex vaccine at one day of age.

All fertile eggs were incubated at $37^{\circ} \mathrm{C}$ with a relative humidity of $80 \%$ from day 0 to 18 in a single setter with the same environmental conditions. After 18 days of incubation eggs were candled and those eggs meeting the requirements were randomly divided into three groups of 100 eggs. Eggs from groups T02 (in ovo treatment) were vaccinated and kept separate by using disconnected isolated hatchers. Eggs from group T03 (at hatch treatment) were transferred to a specific hatcher on day 18 .

At hatch, birds were housed by group in separate HEPA filter isolation rooms. All birds had free access to drinking water. The birds were fed with commercial food appropriate for their age. All feed was sterilized before entering the facilities.

This protocol was submitted to the Zoetis Ethics and Animal Welfare Committee for approval prior to the experiment, and was approved in process 07-15-70AQO.

\section{Management}

To reduce the risk of cross contamination, rooms were accessed in the following order: T01, T02 and T03. Care was taken to prevent cross contamination by wearing personal protective equipment (PPE): shoe covers, gowns, hair nets, and gloves. PPE was changed when moving between rooms. Special care was taken regarding shoe covers, as shoes are the most likely source of cross contamination. Birds were euthanized via cervical dislocation, according to Brazilian Resolution 13 (26SEP2013) from the National Council for Animal Testing Control (CONCEA, acronym in Portuguese).

\section{Experiment 2 - Commercial birds}

All animals used in this experiment were commercial broilers. The sourcing of all eggs used was under the responsibility of the integrator until project completion. Broilers included in this trial were managed according to the standard commercial practices employed by Integrator Unit, under Brazilian regulations of the Ministry of Agriculture, Livestock 
and Food Supply (MAPA, acronym in Portuguese). Sampling and bird management procedures followed national guidelines for animal care and welfare (UBA, 2008).

The selected protocol involved 2 Cobb broiler flocks vaccinated in ovo at 18 days of incubation. Test sites were commercial farms of an industrial company located in the Paraná State where each broiler house had the same kind of equipment and had a housing capacity of 20,000 birds/house. Experimental animals were grouped separately during observational period into two groups: Observation 1, with high level of maternal antibodies and Observation 2, with low level of maternal antibodies.

\section{Sampling}

For both experiments, six chickens from each treatment were necropsied on days $7,14,21,28,35$, and 42. The bursas of Fabricius were selected on the above sampling day per treatment, to be part of the histopathological evaluation with each bursa fixed in $10 \%$ buffered formalin, processed for histological examination and stained by haematoxylin/eosin method. The objective was to evaluate the level of bursal lesions and the onset of virus replication in the organ.

In experiment 1, 20 blood samples were collected from each treatment group at the following ages: 14, 21, 28, 35, and 42 days. In experiment 2, 20 blood samples were taken at 1, 21, and 42 days. ELISA for antibody against IBDV was performed at JF Laboratory using the IDEXX IBD Ab Test Kit (Westbrook Maine USA) for each sample to determine the kinetic of serological profile in different treatments.

\section{Histopathological bursal analysis}

For histopathological score, the global view of all follicles and, principally, their individual responses to the injury were considered. The total percentage of affected follicular distribution was not calculated, and the histopathological evaluation was based on individual follicle histological analysis. For each slide with histological cut of each treatment, two lymphoid follicles were selected randomly to determine the Muskett score. (CHEVILLE, 1967).

The Muskett parameters were adapted to characterize the bursal damage in a graduation appraisal as follows: score 0, normal parenchyma; score 1, very slight medullar necrosis and lymphoid depletion with some heterophil infiltration, moderate edema; score 2, moderate lymphoid depletion with pyknotic nucleus in the medullar and cortical layers, heterophils and macrophage infiltration in the depletion areas; score 3, depletion added to cystic vacuolar formation in the medullar layer, some follicular atrophy and increase in interfollicular space, some cortical necrosis with macrophage activity; score 4, severe lymphoid depletion, increase in interfollicular connective tissue, no separation between cortical and medullar layer, macrophage activity; score 5, complete loss of normal architecture of bursa, very small presence of follicles and lymphocytes, atrophy (MUSKETT et al., 1979).

\section{Statistical analysis}

The data of histopathological analysis of bursas in SPF and commercial birds at different ages are expressed as the arithmetic mean \pm standard deviation (SD) (Table 1 and 2). Kruskall Wallis test ( $P$ $<0.05)$ was used to compare score of bursas between treatments of SPF birds. On the other hand, score of bursas at different level of antibodies were analysed by Wilcoxon test $(P<0.05)$. Both analyses and plots were performed using the ggplot 2 package included in $\mathrm{R}$ software. Only statistically significant results were reported $(P<0.05)$ (Figure 1 and 2$)$. Serological titers were expressed as geometric mean (Figure 3 and 4 ).

\section{RESULTS}

Tables 1 and 2 show the histopathological results from experiments 1 and 2 respectively based on the above criteria. On each sampling day, 6 bursas of Fabricius were evaluated per treatment. An average was calculated for the totality of bursa per treatment.

Histopathological analysis of SPF bird samples allowed the determination of the effect of vaccine strain on the bursal parenchyma over time. In all histopathological evaluations the severity of Muskett's score was significantly different from the unvaccinated control group (Table and Figure 1). In control group, Muskett's score was always close to zero too much that there was no presence of the vaccine strain in the Bursa parenchyma. On the other hand, in vaccinated groups, as the birds had no passive antibodies, this effect of vaccine was noticed from the first evaluation performed at 7 days of age and showed a moderate intensity, consistent with the V877 vaccine strain until the last evaluation week.

Figures 3 and 4 show the serological response in experiments 1 and 2 respectively. An average titer was calculated based on the sampling described above in SPF and commercial birds.

The seroconversion observed in the T02 and T03 groups shows the effect of vaccination in SPF birds without any interference from maternal antibodies (Figure 3). Thus, as early as 14 days, titers were observed in those vaccinated via both in ovo and s.c.. With the absence of antibody titers in T01 group for all ages during this experiment, we can infer there was not cross contamination between treatments and the birds from the T01 group did not have contact with the vaccine or the IBDV from the environment. 
Table 1 - Arithmetic mean \pm standard deviation of histopathological analysis of bursas in SPF birds at different ages in experiment 1 (Muskett's score).

\begin{tabular}{|c|c|c|c|c|c|c|}
\hline Groups & $7 d$ & $14 d$ & $21 d$ & $28 d$ & $35 d$ & $42 d$ \\
\hline $\begin{array}{l}\text { T01 no vaccination - } \\
\text { control }\end{array}$ & $0.33 \pm 0.49^{\mathrm{a}}$ & $0.16 \pm 0.39^{\mathrm{a}}$ & $0.17 \pm 0.39^{\mathrm{a}}$ & $0.25 \pm 0.45^{\mathrm{a}}$ & $0.00 \pm 0.00^{\mathrm{a}}$ & $0.00 \pm 0.00^{\mathrm{a}}$ \\
\hline $\begin{array}{l}\text { T02 - immune complex } \\
\text { vaccine - in ovo }\end{array}$ & $1.42 \pm 0.51^{\mathrm{b}}$ & $2.0 \pm 0.00^{b}$ & $2.0 \pm 0.00^{\mathrm{b}}$ & $1.92 \pm 0.29^{b}$ & $2.00+0.00^{\mathrm{b}}$ & $2.00+0.00^{\mathrm{b}}$ \\
\hline $\begin{array}{l}\text { T03 - immune complex } \\
\text { vaccine - subcutaneous }\end{array}$ & $2.00 \pm 0.00^{\mathrm{b}}$ & $2.00 \pm 0.00^{\mathrm{b}}$ & $1.92 \pm 0.29^{b}$ & $2.40 \pm 0.45^{\mathrm{b}}$ & $2.00 \pm 0.00^{\mathrm{b}}$ & $1.83 \pm 0.39^{\mathrm{b}}$ \\
\hline
\end{tabular}

Averages followed by different letters in the same column are significantly different $(\mathrm{p}<0.05)$, according to the Kruskall Wallis test.

Table 2 - Arithmetic mean \pm standard deviation of histopathological analysis of bursas in commercial birds with different levels of maternal immunity (T1 - high, T2 - low) in different treatments in experiment 2 (Muskett's score)

\begin{tabular}{ccccccc}
\hline Groups & $7 \mathrm{~d}$ & $14 \mathrm{~d}$ & $21 \mathrm{~d}$ & $28 \mathrm{~d}$ & $35 \mathrm{~d}$ & $42 \mathrm{~d}$ \\
\hline $\mathrm{T} 1$ & $1.00 \pm 0.00^{\mathrm{a}}$ & $1.00 \pm 0.00^{\mathrm{a}}$ & $1.00 \pm 0.00^{\mathrm{a}}$ & $2.75 \pm 0.45^{\mathrm{a}}$ & $2.67 \pm 0.49^{\mathrm{a}}$ & $2.58 \pm 0.51^{\mathrm{a}}$ \\
$\mathrm{T} 2$ & $1.00 \pm 0.00^{\mathrm{a}}$ & $1.58 \pm 0.51^{\mathrm{a}}$ & $3.08 \pm 0.29^{\mathrm{b}}$ & $3.00 \pm 0.00^{\mathrm{a}}$ & $2.92 \pm 0.29^{\mathrm{a}}$ & $2.75 \pm 0,45^{\mathrm{a}}$ \\
\hline
\end{tabular}

Averages followed by different letters in the same columm are significantly different $(\mathrm{p}<0.05)$, according to the Wilcoxon test.
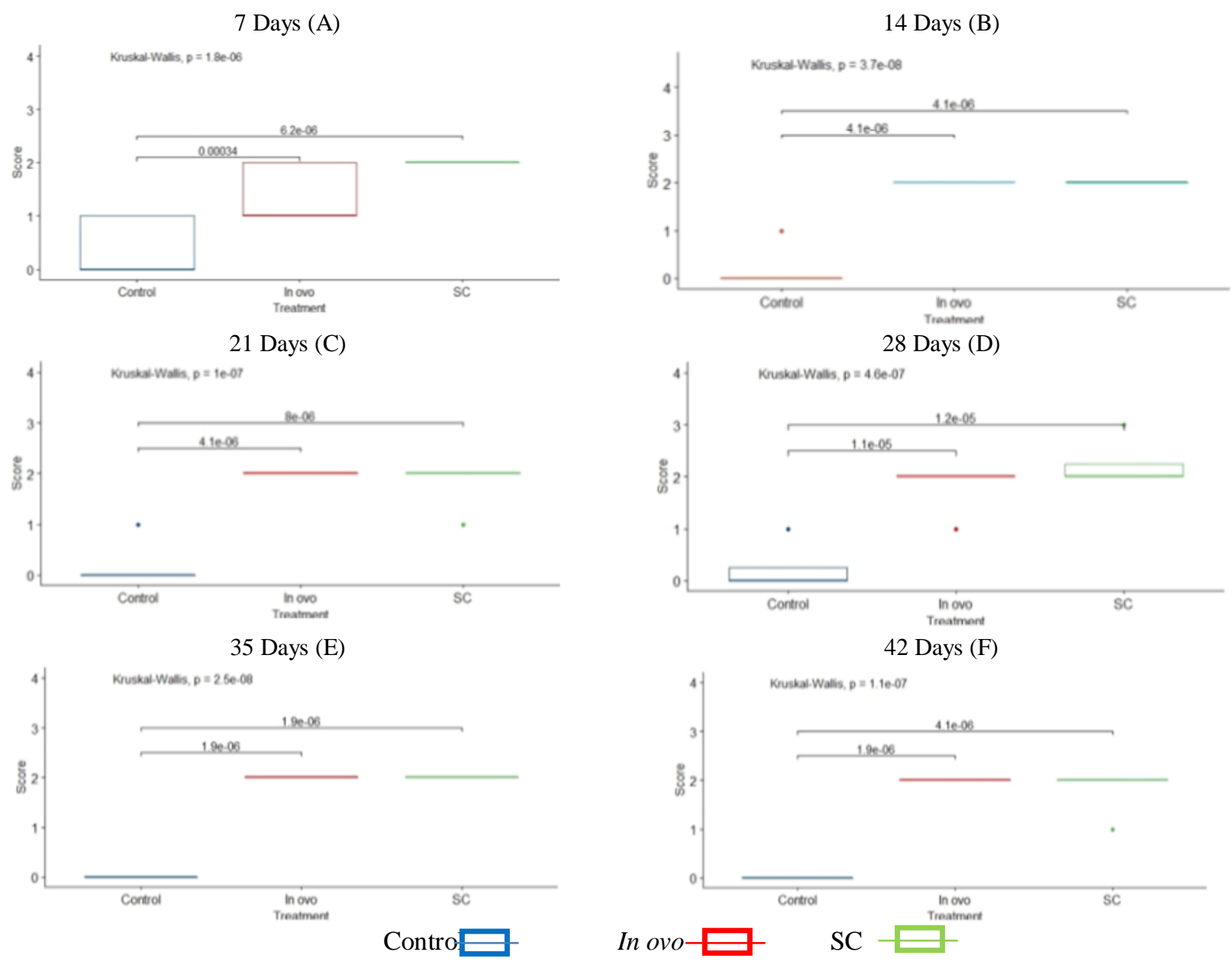

Figure 1 - Statistical analysis of bursas in SPF birds at different ages (7, 14, 21, 28, 35 and 42 days) with significantly differences according to Kruskall Wallis test in experiment 1 (Muskett's score). *SC-Subcutaneous route. 


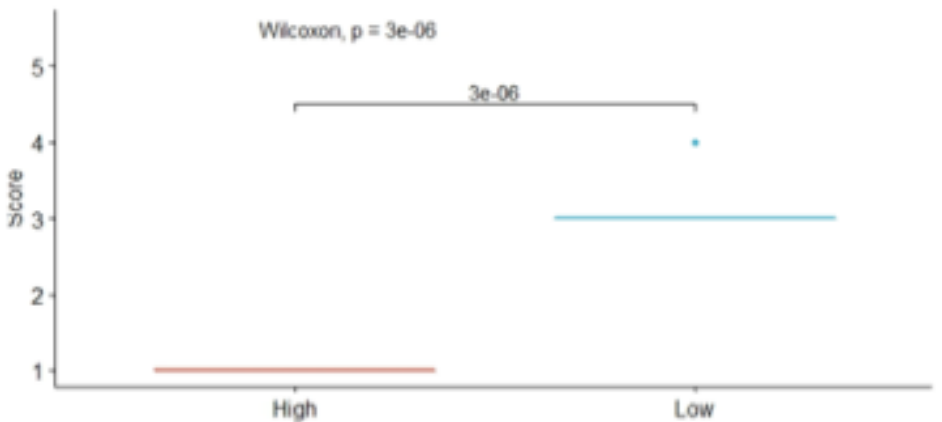

High Low $\square$

Figure 2 - Statistical analysis of bursas in commercial birds with different levels of maternal immunity 21 days postimmunization (T1 - high, T2 - low) according to Wilcoxon test in experiment 2 (Muskett's score)

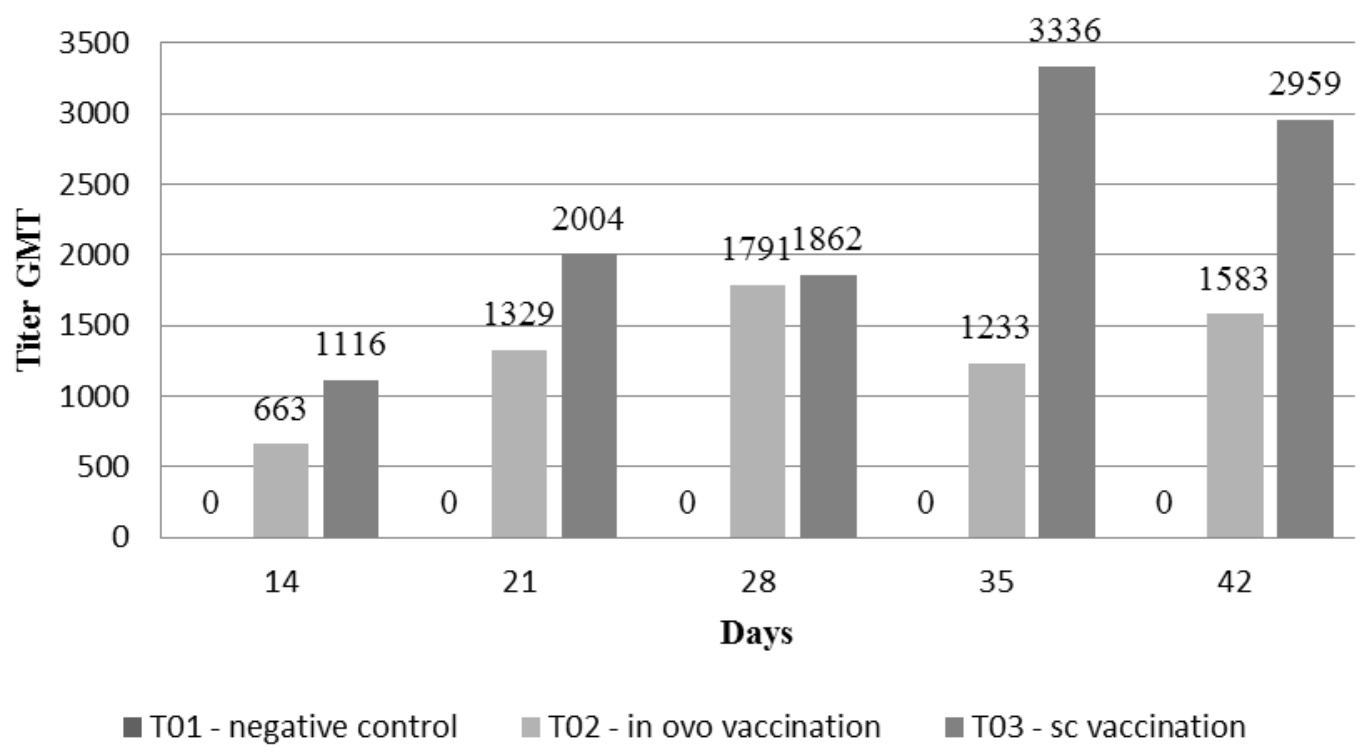

Figure 3 - Serological profile of SPF birds vaccinated with Poulvac Magniplex with different methods of application (geometric mean titer-GMT).

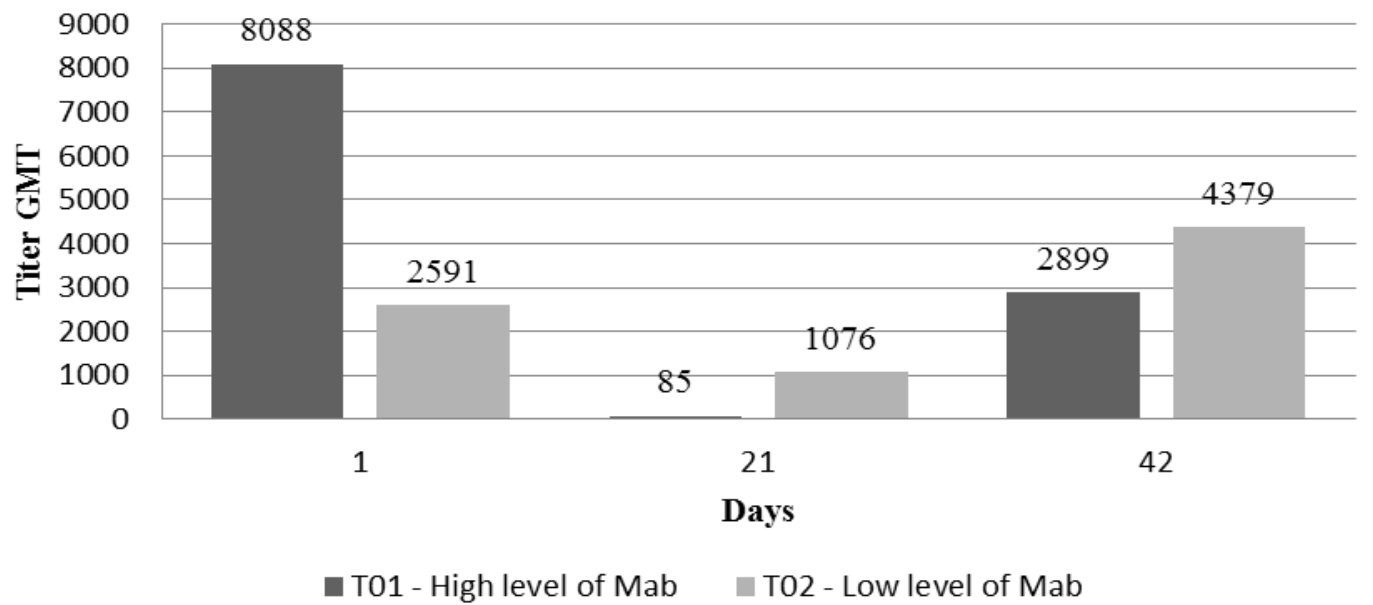

Figure 4 - Serological profile of commercial birds vaccinated with Poulvac Magniplex with different levels of maternal antibodies (Mab) - (geometric mean titer - GMT). 


\section{DISCUSSION}

An important feature within the strains of attenuated IBDV chosen to constitute a vaccine is its capacity of immunogenicity without producing severe lesions in the bursal parenchyma (CAMILOTTI et al., 2011). This avoids the undesirable effect of vaccination inducing some immunosuppression (MORAES et al. 2004). Histopathological results in SPF birds (experiment 1) demonstrated that the immune complex vaccine showed the highest Muskett score, 2.40 at 28 days in the T03 group vaccinated subcutaneously. Furthermore, in subsequent evaluations after 35 and 42 days, the score showed a tendency to drop to 2.00 and 1.83 , clearly demonstrating the regenerative capacity of lymphoid follicles (Table 1 and Figure 5). These results support the use of this V877 strain (GEERLIGS et al., 2015) as a safe vaccine candidate. This regeneration capacity of the lymphoid follicles is related to the integrity of the basement membrane that makes the lining of the follicles where the presence of preserved follicular dendritic cells was observed in the histopathological assessment of vaccinated birds.

The same evaluation in commercial poultry (experiment 2) showed a similar effect of the vaccine strain on the bursal parenchyma, but there was a delay in changes as these birds had passive antibodies. Thus, the effect of vaccine strain was detected significantly only at 28 days of age in field observation 1 where there was a higher level of maternal antibodies on the first day (Table 2). The neutralizing effect of passive antibodies on the moment of "vaccine uptake" is well known and widely discussed in literature about conventional vaccines (MICHELL et al., 2009). The results of this study show that this dynamics occurs in a similar way when vaccines with immune complex technology are used, delaying the detection of the effect of the vaccine strain on the bursal parenchyma of birds that have higher maternal antibodies. (Table and Figure 2).

Both the effect of the vaccine strains and the field virus have been widely reported on the macroscopic and histological appearance of the bursa of Fabricius (Ajhara et al., 2015). The analysis of the histopathological scores between the two experiments, SPF vs commercial birds, showed that commercial birds exhibited more severe lesions in lymphoid follicles than SPF birds in final weeks of the trial. These findings are expected because, in addition to the effect of the vaccine stimulating seroconversion, there is also an ever-present field challenge from the birds' environment (MUNIZ et al., 2017). Generally, in both experiments, bursal lesions indicative of vaccine virus replication was slightly detected from day 14 to 28 onward, reaching a peak at 28 days, for both the s.c. or in ovo schedule. Although no viral load has been measured, histopathological lesions in the bursa parenchyma are an indicator of viral replication. There was strong evidence that passive antibodies interfered with virus activity and multiplication in the bursal parenchyma (Table 2, Figure 2 and 4). Further, there was no evidence of clinical signs attributed to the vaccine or increase in mortality.

Histopathological assessment of follicles from SPF and commercial birds with s.c. and in ovo expositions showed different lesions have mostly been follicular depletion and follicle atrophy currently observed with hot strains of IBD vaccines (ELMANDY et al., 2013). On the other hand, it was possible to realize a mix of residual lesions and follicles with repopulation evidence and parenchymal recovering at 35 and 42 days (Tables 1 and 2). In this way, lesions and follicles in recovery were not present in a parsimoniously distributed way. There were injured follicles close to depletives or fibrosed. Different levels of scores can be found in the same lymphoid parenchyma analyzed (Figure 5). The present results agree with previous studies because they have shown that in ovo vaccination with an immune complex vaccine (IBDV-BDA) caused transient bursal destruction in both SPF and maternally protected broiler groups with differences evident in starting time, severity and duration of the effect (IVÁN et al., 2001).

Comparative serological analysis of two different field situations, field observation 1 at day 1 showed higher level of passive antibodies than in field observation 2, and at day 42 the antibody levels were higher in field observation 2 than those of field observation 1. This active seroconversion already started at 21 days, which ended with high titers on day 42 in field observation 2 . On the other hand, in Field observation 1 , seroconversion only reached a plateau after 42 days (Figure 4). This shows the interference of maternal antibodies in the active serological response in birds vaccinated with immune complex vaccine. This observation seems to be related to the difference in repopulation and intensity of bursal parenchyma lesions in the different situations. Studies of experimental inoculations with virulent and vaccine strains have demonstrated that the serological response depends on the regeneration of lymphoid tissue and repopulation of the lymphoid follicles of the bursa of Fabricius (KIM et al., 1999).

Furthermore, when comparing the level of antibodies at day 42 between the two experiments, in SPF layers (experiment 1) and commercial broilers (experiment 2), it is possible to infer that field observations demonstrated that the presence of field challenges induced a higher antibody production level against bursal disease in previously vaccinated birds (Figures 3 and 4). This antibody response is expected in vaccinated birds and is the main defense against the field challenge, especially in the case of Gumboro disease, in which humoral immune response plays an important role in protecting against the field virus by neutralizing the agent (Müller et al., 2012). On the other hand, the lower level of seroconversion observed in vaccinated SPF birds (except the unvaccinated control group with absence of titer) demonstrates only the effect of the vaccine, since as the birds were isolated from the environment there was no field challenge. Research related to the immune response in different bird types demonstrates a significant influence of chickens' genetic background on disease 
outcome and on immune response (Vervelde et al., 2011; EMAN et al., 2013). Moreover, the difference between backgrounds in IBDV susceptibility is further influenced by the virulence of the infecting virus strain (ARICIBASI et al., 2010).

In most studies, it has been clearly indicated that chickens vaccinated at embryonic stage acquired higher antibody levels that are sustained at high levels over the normal broiler's rearing period (NEGASH et al., 2004). Nevertheless, in the experiment 1 of this study, where SPF Leghorn birds were used, the serological titers obtained in the final weeks in subcutaneously vaccinated birds were slightly higher than those in birds vaccinated in ovo (Figure 3). A high Muskett's score was also observed in the tissues at 28 days in birds vaccinated subcutaneously where the average score reached 2.40. Other experiments should be conducted to better understand the reason for these findings.

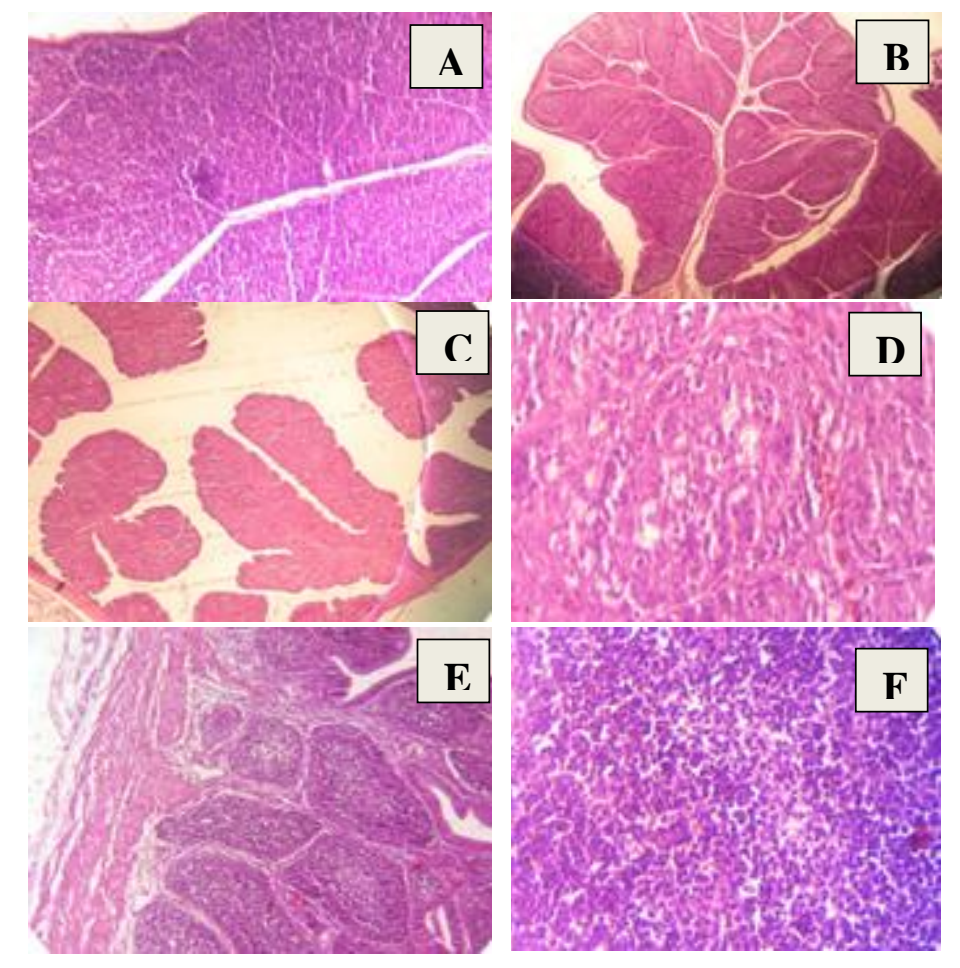

Figure 5 - Microscopic view of general histopathology of birds in different levels of bursal score. (A) Normal view of bursal tissue. Note the follicles' integrity $(100 \mathrm{x})$; (B) In vaccinated chickens, medullary area from several follicles shows depletion and retraction. Slide also shows normal follicles (40 x). (C )Many follicles show atrophy or are experiencing regressive changes $(40 \mathrm{x})$. (D) Higher magnification of the regressive changes as above, mostly in the central follicle. BM is preserved $(400 \mathrm{x})$. (E) Some follicles show repopulation patterns. There is also some degree of fibroblastic reaction and residual atrophy (40x). (G) Higer magnification of a repopulated follicle (400 x).

\section{CONCLUSION}

Based on the data presented in this study, it can be concluded that the effect of the immune complex vaccine is complementary to maternal antibodies. Under both experimental and field conditions, with SPF or commercial birds, the immune complex vaccine works in the absence of or with different levels of passive antibodies and the vaccine virus starts to replicate at the most appropriate time to provide the animal with active immunity.

\section{ACKNOWLEDMENTS}

The authors wish to acknowledge the assistance provided by Igor L. dos Santos during the management procedures and handling of the birds at the CPABR Laboratory. Special thanks to Dany Mesa from UFPR for running the statistical analysis.

\section{REFERENCIAS}

AJHARA, N.; HORIUCHI, N.; HIKICHI, N.; OCHIAI, M.; HOSODA, Y.; ISHIKAWA, Y.; SHIMAZAKI, Y.; OISHI, K. Immunoreactivity and morphology changes of bursal follicles in chicken infected with vaccine or wild-type strains of the infectious bursal disease virus. The Journal of Veterinary Medical Science, Tokyo, 77(8): 913-918, 2015.

ARICIBASI, M.; JUNG, A.; HELLER, E. D.; RAUTENSCHLEIN, S. Differences in genetic background influence the induction of innate and acquired immune responses in chickens depending on the virulence of the infecting infectious bursal disease virus (IBDV) strain. Veterinary Immunology and Immunopathology, 135, 1-2, 79-92, 2010. 
BLOCK, H.; MEYER-BLOCK, K.; REBESKI, D. E.; SCHARR, H.; DE WIT, S.; ROHN, K.; RAUTENSCHEIN, S. A field study on the significance of vaccination against infectious bursal disease virus (IBDV) at the optimal time point in broiler flocks with maternally derived IBDV antibodies. Avian Pathology, London; 36; 401-409, 2007.

CAMILOTTI, E.; MORAES, L. B.; FURIAN, T.; BORGES, K. A.; MORAES, H. L. S.; SALLE, F. O.; SALLE, C. T. P. Infectious Bursal Disease: Evaluation of the Pathogenicity and Immunogenicity of Commercial Vaccines in Brazil. In: 60 $^{\text {th }}$ Western Poultry Disease Conference, Sacramento, March 2023, 2011.

CHEVILLE, N. F. Studies on the pathogenesis of the IBD in the bursa of Fabricius, spleen, and thymus of the chicken. American Journal of Pathology, 51(4): 527-551, 1967.

CONCEA, BRASIL. Resolution 13 (26 september 2013) from the National Council for Animal Testing Control, DOU n ${ }^{\circ} .187,1$, p. 5, 2013.

EL-MAHDY, S. S.; FAROUK, H.; ABB EL-WANIS, N. A.; HAMOUD, M. M.. Comparative studies between different commercial types of live Infectious bursal disease [IBD] vaccine strains in Egypt. American Journal of Research Communication, 10:113-129, 2013.

EMAN, M.; MEHARABANI-YEGANEH, H.; BARJESTEH, N.; NIKBAKHT, G.; THOMPSONCRISPI, K.; CHARKHKAR, S.; MALLARD, B. The influence of genetic background versus commercial breeding programs on chicken immunocompetence . Poultry Science, 93:1(1):77-84, 2104. https://doi.org/10.3382/ps.2013-03475

GEERLIGS, H. J.; ONS, E.; BOELM, G. J.; VANCRAEYNEST, D. Efficacy, Safety, and Interactions of a Live Infectious Bursal Disease Virus Vaccine for Chickens Based on Strain IBD V877. Avian Diseases, Jacksonville, 59: 494-500, 2015.

IVÁN, J.; NAGY, N.; MAGYAR, A.; KACSKOVICS, I.; MÉSZÁROS, J. Functional restoration of bursa of Fabricius following in ovo infectious bursal disease vaccination. Veterinary Immunology Immunopathology, May 30; 79 (3-4): 235-248, 2001.

IVÁN, J.; VELHNER, M.; URSU, K.; GERMÁN, P.; MATÓ, T.; DRÉN, C. N.; MÉSZÁROS, J. Delayed vaccine virus replication in chickens vaccinated subcutaneously with an immune complex infectious bursal disease vaccine: quantification of vaccine virus by real-time polymerase chain reaction. Canadian Journal of Veterinary Research, 69:135-142, 2005.

JEURISSEN, S. H.; JANSE, E. M.; LEHRBACH, P. R.; HADDAD, E. E.; AVAKIAN, A.; WHITFILL, C. E. The working mechanism of an immune complex vaccine that protects chickens against infectious bursal disease. Immunology, 95:494-500, 1998.

KIM, J.; GAGIC, M.; SHARMA, J. M. Recovery of antibody-producing ability and lymphocyte repopulation of bursal follicles in chickens exposed to infectious bursal disease virus. Avian Diseases, Jacksonville, 43:401-413, 1999.

MICHELL, B. C.; GOMES, A. D.; BAIÃO, N. C.; RESENDE, M.; LARA, L. J. C.; MARTINS, N. R. S. Effect of maternally-derived antibodies on the performance and immunity of broilers induced by in ovo or post-hatching immunizations with a live vaccine against Infectious Bursal Disease. Brazilian Journal of Poultry Science, Campinas, 11(1): 57-63, 2009.

MORAES, H. L. S.; SALLE, C. T. P.; PADILHA, A. P.; NASCIMENTO, V. P.; SOUZA, G. F.; PEREIRA, R. A.; ARTENCIO, J. O.; SALLE, F.O. Infectious Bursal Disease: Evaluation of Pathogenicity of Commercial Vaccines from Brazil in Specific Pathogen Free Chickens. Brazilian Journal of Poultry Science, Campinas, 7(1):51-57, 2004.

MÜLLER, H.; MUNDT, E.; ETERRADOSSI, N.; ISLAM, R. Current status of vaccines against infectious bursal disease. Avian Pathology, London, 41(2):133-139, 2012.

MUNIZ, E. C.; VERDI, R.; JACKWOOD, D.J.; KUCHPEL, D.; RESENDE, M. S.; MATTOS, J. C. Q.; COOKSON, K. Molecular epidemiologic survey of infectious bursal disease viruses in broiler farms raised under different vaccination programs. The Journal of Applied Poultry Research, Oxford, 2017, pfx043; https://doi.org/10.3382/japr/pfx043

MUSKETT, J. C.; HOPKINS, I. G.; EDWARDS, K. P.; THORNTON, D. H. Comparison of two infectious bursal disease vaccine strains: Efficacy and potential hazards in susceptible and maternally immune birds. Veterinary Record, 104:332-334, 1979.

NEGASH, T.; AL-GARIB, S. O.; GRUYS, E. Comparison of in ovo and post-hatch vaccination with particular reference to infectious bursal disease. A review. Veterinary Quarterly, London, 26(2):76-87, 2004.

VERDELDE, L.; DE GEUS, E.; JANSEN, C.; HELLER, D.E. Contribution of the genetic background to the imune response of broilers vaccinated or challenged with LPAI H9N2. BMC Proceedings20115 (Suppl 4):S5, 2011.

OIE. Infectious Bursal Disease (Gumboro Disease). In: Manual of Diagnostic Tests and Vaccines for Terrestrial Animals 2008. $6^{\text {th }}$ ed., chap. 2.3.12, p. 549-565, 2011.

UBA - Protocolo de Boas Práticas de Produção de Frangos, jun/2008 - ABPA 295 http://abpabr.com.br/files/publicacoes/c0b265b96f89355016b388 2d5976fc49.pdf 